Article

\title{
Thermally Stable and Reusable Ceramic Encapsulated and Cross-Linked CalB Enzyme Particles for Rapid Hydrolysis and Esterification
}

Min Song ${ }^{1,2}$ and Jeong-Ho Chang ${ }^{1, *}$

check for

updates

Citation: Song, M.; Chang, J.-H.

Thermally Stable and Reusable

Ceramic Encapsulated and CrossLinked CalB Enzyme Particles for Rapid Hydrolysis and Esterification. Int. J. Mol. Sci. 2022, 23, 2459.

https://doi.org/10.3390/

ijms23052459

Academic Editors: Caterina Cinti, Elisa Martella, Ambra Giannetti and Sara Tombelli

Received: 24 January 2022

Accepted: 21 February 2022

Published: 23 February 2022

Publisher's Note: MDPI stays neutral with regard to jurisdictional claims in published maps and institutional affiliations.

Copyright: (C) 2022 by the authors. Licensee MDPI, Basel, Switzerland. This article is an open access article distributed under the terms and conditions of the Creative Commons Attribution (CC BY) license (https:// creativecommons.org/licenses/by/ $4.0 /)$
1 Korea Institute of Ceramic Engineering and Technology, Cheongju 28160, Korea; sm_0704@naver.com

2 Department of Materials Science \& Engineering, Yonsei University, Seoul 03722, Korea

* Correspondence: jhchang@kicet.re.kr

\begin{abstract}
Candida antarctica lipase B (CalB) enzyme was encapsulated and cross-linked by silica matrix to enhance its thermal stability and reusability, and demonstrated an enzymatic ability for rapid hydrolysis and esterification. Silica encapsulated CalB particles (Si-E-CPs) and silica cross-linked CalB particles (Si-CL-CPs) were prepared as a function of TEOS concentration. The particle size analysis, thermal stability, catalytic activity in different $\mathrm{pHs}$, and reusability of Si-E-CPs and Si-CL-CPs were demonstrated. Furthermore, the determination of the CalB enzyme in Si-E-CPs and Si-CL-CPs was achieved by Bradford assay and TGA analysis. Enzymatic hydrolysis was performed against the p-nitrophenyl butyrate and the catalytic parameters $\left(\mathrm{K}_{\mathrm{m}}, \mathrm{V}_{\max }\right.$, and $\left.\mathrm{K}_{\mathrm{cat}}\right)$ were calculated by the Michaelis-Menten equation and a Lineweaver-Burk plot. Moreover, enzymatic synthesis for benzyl benzoate was demonstrated by esterification with an acyl donor of benzoic acid and two acyl donors of benzoic anhydride. Although the conversion efficiency of Si-CL-CPs was not much higher than that of native CalB, it has an efficiency of $91 \%$ compared to native CalB and is expected to be very useful because it has high thermal and $\mathrm{pH}$ stability and excellent reusability.
\end{abstract}

Keywords: thermal stability; reusability; silica; encapsulation; cross-linking; CalB enzyme; benzyl benzoate

\section{Introduction}

Lipases have been used in various industries, such as agriculture, medicine, pharmaceuticals, and cosmetics, due to their high activity and regioselectivity [1-5]. Lipases work under mild conditions (neutral $\mathrm{pH}$, low temperature) and are completely biodegradable, to reduce chemical consumption and waste generation, attracting attention as a green biocatalyst [6-8]. Lipases generally catalyze a hydrolysis reaction, but they effectively perform synthesis reactions (esterification, acylation, etc.) in a non-aqueous or low-water environment $[9,10]$. Among lipases, Candida antarctica lipase B (CalB) is the prominent biocatalyst in several industrial applications, due to its wide range of substrates, high efficiency and enantioselectivity, thermal stability, and stability in organic solvents [11-13]. Structurally, CalB is composed of catalytic triad (Ser, His, and Asp/Glu) within an acyl binding pocket [14]. The active site consists of the acyl binding pocket and a binding pocket for the moiety of secondary alcohols [11]. Furthermore, the active site of CalB is not covered by a lid and, thus, the active site for the hydrophobic substrate is directly accessible to the solvent [15]. CalB is used in a wide range of organic syntheses, such as aminolysis, esterification, and transesterification, due to those characteristics [16].

However, lipases suffer several drawbacks in the commercialization process. Lipases are difficult to recover from an aqueous reaction mixture due to their high solubility in water [17]. Also, it is difficult to maintain the structural stability of proteins during biochemical reactions, which may affect the biological activity of lipase [18,19]. Generally, lipases are sensitive to process conditions other than the optimal conditions, normally 
a narrow $\mathrm{pH}$ range, and low thermal stability [15]. In addition, lipases incur high costs during production and processing due to their low long-term operation stability and short storage life $[20,21]$.

Enzyme immobilization is an efficient method that can overcome these limitations. Enzyme immobilization improves the stability of lipase and allows easy recovery from an aqueous reaction mixture, reuse of lipase, and a continuous operation process [22,23]. The cost of using encapsulated lipase in continuous processes is more than 20 times lower than that of conventional processes, which can effectively reduce costs $[19,23,24]$. In general, the enzyme immobilization method can be divided into binding or encapsulating to an organic and inorganic support, and by cross-linking of the protein molecule [25,26]. Binding to a carrier can enhance lipase stability by preventing direct contact with the external environment and improve resistance to thermal and chemical denaturation [27-30]. Enzyme encapsulation technology using a silica matrix has recently been demonstrated as an effective method for enzyme entrapment [31,32]. A silica matrix is chemically inert and has higher mechanical strength than most organic polymers and, thus, works stably in organic synthesis [33,34]. Moreover, silica gels can easily be tailored to network textures, a large range of porous surfaces and processing conditions [33]. However, they may produce low productivity and effects on enzymatic activity due to lipase distortion between the lipase and the support, active site blocking by the silica support and diffusion problems $[35,36]$. In contrast, immobilization by the cross-linking of enzyme molecules, which we called cross-linked enzyme aggregates (CLEA), is a carrier-free method and comprises active enzymes $[37,38]$. Thus, the volumetric activity of CLEA is much higher than that of both conventional and immobilized enzymes [39]. However, CLEA exhibited low activity retention, and low stability in mechanical strength and under heat and organic solvents [25]. Therefore, it is necessary to study immobilized enzymes that are stable from protein denaturation, while having high enzymatic activity.

In this work, Candida antarctica lipase B (CalB) was encapsulated and cross-linked by tetraethyl orthosilicate (TEOS), as a silica precursor to enhance the enzyme stability. Silicaencapsulated CalB particles (Si-E-CPs) and silica-cross-linked CalB particles (Si-CL-CPs) were prepared as a function of TEOS concentration, in a range of $10 \mathrm{mM}$ to $300 \mathrm{mM}$. The particle size analysis, thermal stability $\left(25-65^{\circ} \mathrm{C}\right)$, catalytic activity in different $\mathrm{pHs}(\mathrm{pH}$ 5-9), and reuseability of Si-E-CPs and Si-CL-CPs were demonstrated in comparison a with native CalB enzyme. Furthermore, the determination of the CalB enzyme in Si-E-CPs and Si-CL-CPs was achieved by Bradford assay and TGA analysis. With these materials, we achieved enzymatic hydrolysis and a synthesis reaction, as shown in Figure 1. Enzymatic hydrolysis was performed against the $p$-nitrophenyl butyrate ( $p$-NPB) and the catalytic parameters, such as $\mathrm{K}_{\mathrm{m}}, \mathrm{V}_{\max }$, and $\mathrm{K}_{\mathrm{cat}}$, which were calculated by the Michaelis-Menten equation and Lineweaver-Burk plot.

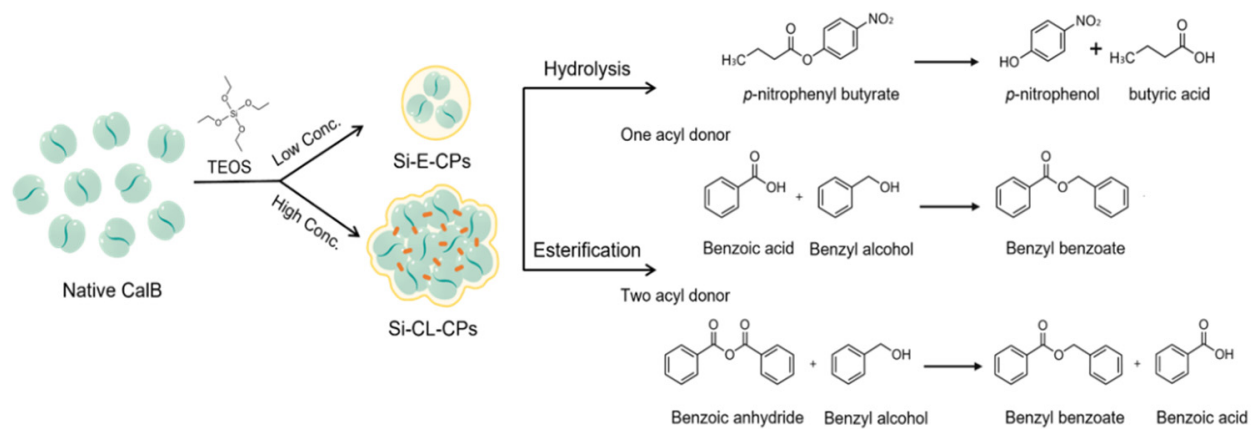

Figure 1. Schemes of silica encapsulation and cross-linking on CalB enzyme with different.

TEOS concentrations and application to enzymatic hydrolysis and esterification.

In addition, we synthesized benzyl benzoate, an aromatic ester, by esterification and acylation using two acyl donors, benzoic anhydride and benzoic acid with native CalB and 
Si-CL-CPs. The synthetic efficiency for benzyl benzoate with native CalB and Si-CL-CPs was calculated and an available mechanism is suggested.

\section{Results and Discussion}

\subsection{Preparation and Characterization of $S i-E-C P s$ and $S i-C L-C P s$}

Si-E-CPs and Si-CL-CPs were prepared by control of the TEOS concentration on the CalB enzyme, in the range of 10 to $50 \mathrm{mM}$, and 100 to $300 \mathrm{mM}$, respectively. Figure 2a shows the SEM images of the prepared Si-E-CPs, and Si-CL-CPs with different particles sizes by TEOS concentrations. At lower concentrations, such as $10 \mathrm{mM}, 30 \mathrm{mM}$, and $50 \mathrm{mM}$ of TEOS on the CalB enzyme, Si-E-CPs were uniformly spherical particles and showed the size of $0.46 \mu \mathrm{m}, 0.89 \mu \mathrm{m}$, and $1.41 \mu \mathrm{m}$, respectively. At higher concentration of TEOS, such as $100 \mathrm{mM}, 200 \mathrm{mM}$, and $300 \mathrm{mM}$, Si-CL-CPs were obtained with increasing particle sizes of $5.30 \mu \mathrm{m}, 12.86 \mu \mathrm{m}$, and $14.73 \mu \mathrm{m}$, respectively. In the sol-gel reaction, when the concentration of TEOS increases and reaches the supersaturation region, both the hydrolysis and condensation rates are accelerated, increasing the consumption rate of the intermediate through the condensation reaction. This phenomenon causes aggregation of the silica and the enzyme, and the generated gel networks act as a cross-linking agent between the enzyme and the silica. Therefore, the particle size of synthesized silica-enzyme aggregates are relatively larger than colloidal silica [40-42]. Fourier transform infrared (FT-IR) spectra of native CalB, Si-E-CPs, and Si-CL-CPs are shown in Figure 2b. The several characteristic vibrations for each sample were observed as follows. The $\mathrm{N}-\mathrm{H}$ stretching and $\mathrm{O}-\mathrm{H}$ stretching vibrations were observed at $1660 \mathrm{~cm}^{-1}$ and $1550 \mathrm{~cm}^{-1}$ and at $3400 \mathrm{~cm}^{-1}$, respectively. Moreover, the asymmetric and symmetric stretching vibrations of $\mathrm{Si}-\mathrm{O}-\mathrm{Si}$ bond are seen at $1100 \mathrm{~cm}^{-1}$ and $800 \mathrm{~cm}^{-1}$, in which this result indicated that the native CalB enzyme was successfully encapsulated and cross-linked with silica precursor TEOS.

(a)
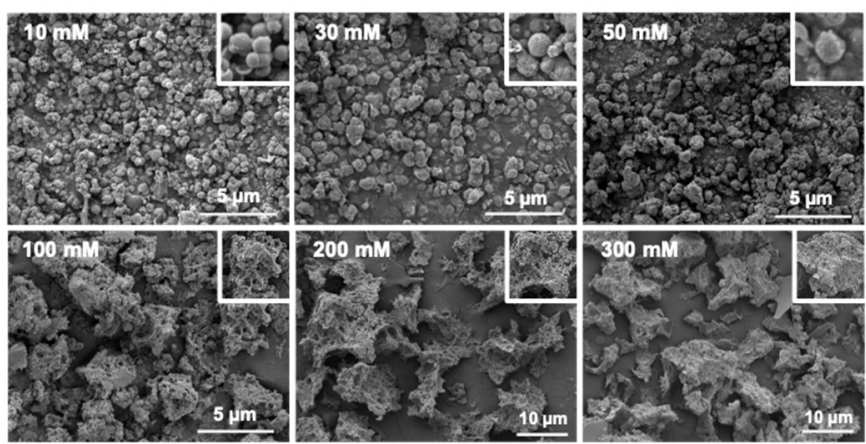

(b)

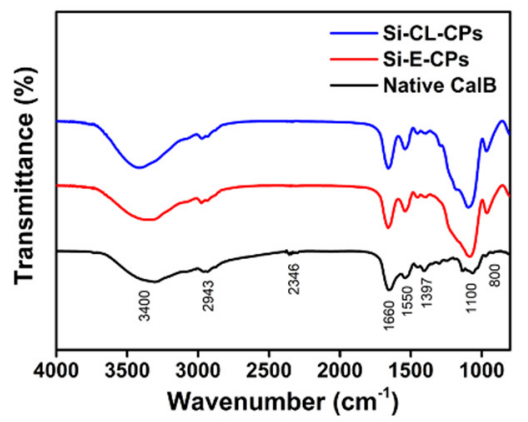

(c)

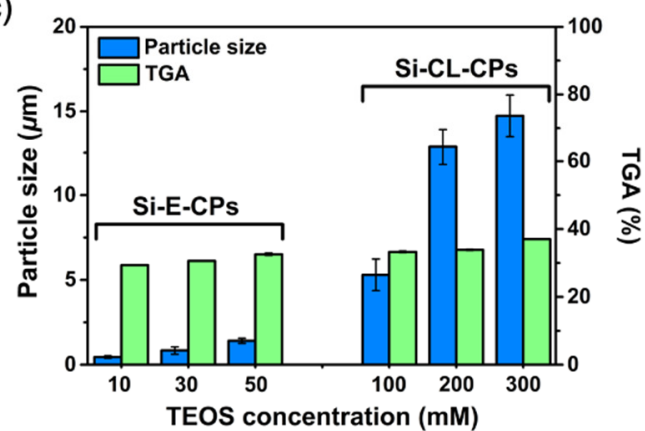

(d)

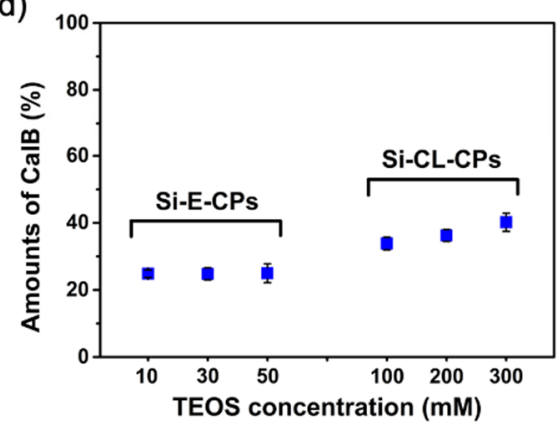

Figure 2. The (a) SEM images of silica encapsulation and cross-linking on CalB enzyme as a function of TEOS concentration, (b) FT-IR spectra of native CalB, Si-E-CPs, and Si-CL-CPs), (c) correlations of particle sizes and TGA analysis of Si-E-CPs and Si-CL-CPs as a function of TEOS concentration, and (d) determination of CalB enzyme in Si-E-CPs and Si-CL-CPs by Bradford assay.

Figure $2 \mathrm{c}$ shows the relationship between the particle size and thermogravimetric analysis (TGA) of Si-E-CPs and Si-CL-CPs as a function of the TEOS concentration. TGA 
analysis was performed to investigate the amount of CalB enzyme in Si-E-CPs and Si-CL$\mathrm{CPs}$ and was calculated in the temperature range of $200-500{ }^{\circ} \mathrm{C}$. At lower concentrations such as $10 \mathrm{mM}, 30 \mathrm{mM}$, and $50 \mathrm{mM}$ of TEOS, the amounts of CalB enzyme in Si-E-CPs were slightly increased to $29.78 \%, 31.86 \%$ and $33.13 \%$, respectively. At higher concentrations of TEOS such as $100 \mathrm{mM}, 200 \mathrm{mM}$, and $300 \mathrm{mM}$, the amounts of CalB enzyme in Si-CL-CPs were $33.96 \%, 34.28 \%$, and $37.08 \%$, respectively. The amount of CalB enzyme in Si-E-CPs and Si-CL-CPs particles seems to increase slightly with increasing reactive TEOS concentration, but the amount of CalB enzyme reacting with silica is always constant and therefore the same. In addition, Bradford assay was further demonstrated using Coomassie brilliant blue reagent to determine the CalB enzyme in Si-E-CPs and Si-CL-CPs as a function of TEOS concentration as shown in Figure $2 \mathrm{~d}$. The amounts of CalB enzyme as a function of TEOS concentration were $24.83 \%, 24.80 \%, 24.97 \%$, corresponding to $10 \mathrm{mM}, 30 \mathrm{mM}$, and $50 \mathrm{mM}$, and $33.83 \%, 36.22 \%$ and $40.17 \%$ corresponding to $100 \mathrm{mM}, 200 \mathrm{mM}$, and $300 \mathrm{mM}$, respectively. The average amounts of CalB enzymes in Si-E-CPs and Si-CL-CPs were $24.87 \%$ and $36.74 \%$, respectively. The concentration of TEOS increased in Si-E-CPs, but the amount of CalB enzyme in Si-E-CPs was almost the same as the amount of CalB enzyme reacting with silica, which was constant. In addition, the amount of CalB enzyme in Si-CL-CPs was $36.74 \%$, which was higher than that of Si-E-CPs because the high concentration of TEOS randomly contained the CalB enzyme remaining around silica during a very fast sol-gel condensation reaction.

\subsection{Thermal Stability, $p H$ Activity, and Reusability of Si-E-CPs and Si-CL-CPS}

Determination of thermal stability and $\mathrm{pH}$ activity for native CalB, Si-E-CPs, and Si-CL-CPs are very important to understand how lipase encapsulation affects enzyme activity. In general, sol-gel encapsulated enzymes have been reported to have higher stability than native CalB [43]. The catalytic activities of native CalB, Si-E-CPs, and Si-CL$\mathrm{CPs}$ were investigated with hydrolysis of $\mathrm{p}-\mathrm{NPB}$, in the temperature range of $25-65{ }^{\circ} \mathrm{C}$ to access the thermal stability of the enzyme. Figure 3a shows the catalytic activity of native CalB, Si-E-CPs, and Si-CL-CPs as a function of temperature. The optimum thermal activities are seen at $35{ }^{\circ} \mathrm{C}$, and the activities decreased at higher temperatures, above $35^{\circ} \mathrm{C}$. Moreover, Si-E-CPs and Si-CL-CPs are much more stable than the native CalB due to the encapsulated and cross-linked silica matrix. The thermal stability of Si-E-CPs is slightly better than that of Si-CL-CPs by the perfect silica encapsulation. Figure $3 \mathrm{~b}$ shows the effect of $\mathrm{pH}$ on the catalytic activity of native CalB, Si-E-CPs, and Si-CL-CPs, in the $\mathrm{pH}$ range of 5-9. The optimum $\mathrm{pH}$ for catalytic activities of the samples is seen at $\mathrm{pH} 7$ and the activities decreased at lower and higher $\mathrm{pH}$. This result means that the activity of the enzyme, according to the $\mathrm{pH}$ change, depends on the catalytic activity at a specific $\mathrm{pH}$ of the enzyme, regardless of the silica immobilization process, such as encapsulation and cross-linking. Figure 3c shows the comparison of reusability with Si-E-CPs, and Si-CL-CPs. The greatest advantage of silica immobilization on the enzyme is that expensive enzymes can be repeatedly used. The native CalB enzyme is easily dissolved in an aqueous solution and hard to re-use because the recovery is not easy. To evaluate the reusability, Si-E-CPs and Si-CL-CPs were recovered seven times and the Si-E-CPs and Si-CL-CPs were washed with buffer solution after each cycle.

As a result, it was confirmed that the catalytic activity of Si-E-CPs and Si-CL-CPs was still maintained over $90 \%$ after fifth usage. These results mean that the Si-E-CPs and Si-CL-CPs can be used efficiently in a continuous process without activity loss. 
(a)

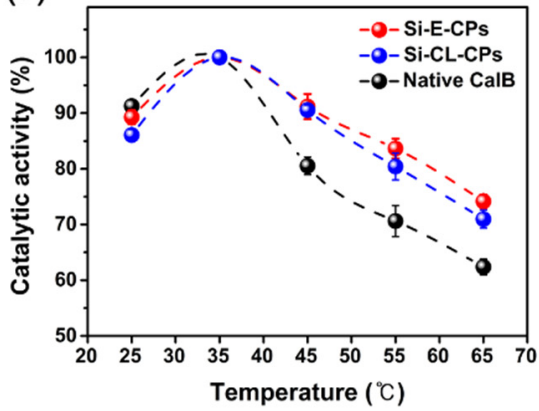

(b)

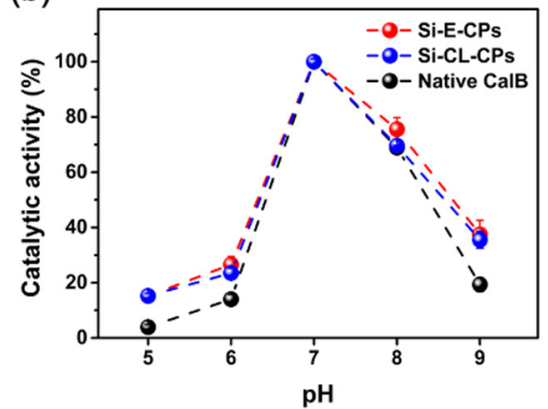

(c)

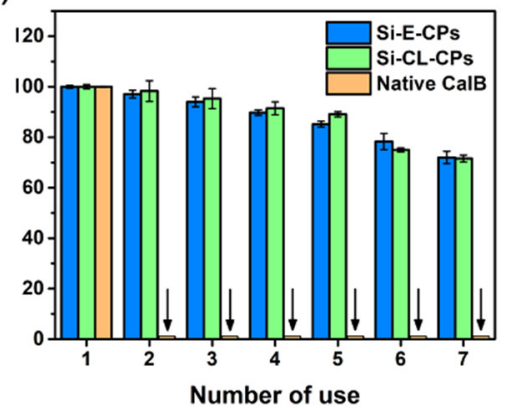

Figure 3. (a) Thermal stability and (b) catalytic activity in $\mathrm{pHs}$ with native CalB, Si-E-CPs, and Si-CL-CPs, and (c) reusability of Si-E-CPs and Si-CL-CPs.

\subsection{Enzymatic Hydrolysis for p-Nitrophenyl Butyrate}

Enzymatic hydrolysis was demonstrated for the hydrolysis of p-nitrophenyl butyrate (p-NPB), using native CalB, Si-E-CPs, and Si-CL-CPs, as shown in Figure 4a. The p-NPB is hydrolyzed to $\mathrm{p}$-nitrophenol ( $\mathrm{p}-\mathrm{NP}$ ) and butyric acid by enzyme catalysts. The absorbance of the product $\mathrm{p}-\mathrm{NP}$ was measured with a UV-Vis. spectrophotometer at a wavelength of $400 \mathrm{~nm}$. Figure $4 \mathrm{~b}$ shows the concentration of the formed $\mathrm{p}-\mathrm{NP}$ through the hydrolysis of p-NPB for native CalB, Si-E-CPs, and Si-CL-CPs, respectively. The enzymatic p-NPB hydrolysis in native CalB, Si-E-CPs, and Si-CL-CPs was shown in the order of native CalB $>\mathrm{Si}-\mathrm{CL}-\mathrm{CPs}>\mathrm{Si}-\mathrm{E}-\mathrm{CPs}$ at the initial reaction. This is due to several reasons. First, the higher the amount of CalB contained in the catalyst, the faster the catalytic reaction. Calculating the amount of CalB in native CalB, Si-E-CPs, Si-CL-CPs for enzymatic p-NPB hydrolysis is $36.79 \mu \mathrm{g}, 36.74 \mu \mathrm{g}, 24.87 \mu \mathrm{g}$, respectively, since $24.87 \%$ and $36.74 \%$ of CalB are contained in the Si-E-CPs, and Si-CL-CPs on average, the amount of CalB in $0.1 \mathrm{mg}$ of each Si-E-CPs, $\mathrm{Si}-\mathrm{CL}-\mathrm{CPs}$ is calculated. The production efficiency of $\mathrm{p}-\mathrm{NP}$ is shown in the order of native CalB $>$ Si-CL-CPs $>$ Si-E-CPs, which has a tendency of CalB $>$ Si-CL-CPs $>$ Si-E-CPs, such as the order of CalB content of the catalyst used. It is noteworthy that, although the amount of native CalB and the amount of CalB in Si-CL-CPs are almost the same as $36.79 \mu \mathrm{g}$ and $36.74 \mu \mathrm{g}$, the efficiency of p-NP production is much better in native CalB than in Si-CL$\mathrm{CPs}$. This shows that the active sites of CalB enzyme are masked or shielded by bonding with silica, so that the hydrolysis efficiency of Si-CL-CPs is lower than that of native CalB. Second, when comparing the silica cross-linking process with the encapsulation process, the active sites of the CalB enzyme that can interact with the p-NPB substrate are masked or shielded more in the encapsulation process than in the cross-linking process, so that the hydrolysis efficiency is improved, such as Si-CL-CPs > Si-E-CPs. Third, the amount of CalB of Si-E-CPs by the encapsulation process is $24.87 \mu \mathrm{g}$, which is less than $36.74 \mu \mathrm{g}$ of Si-CL-CPs, so it can be inferred that the efficiency of p-NP production is lower than that of Si-CL-CPs. In addition, considering the internal diffusion limitations of Si-E-CPs and Si-CL-CPs, it is expected that Si-CL-CP will be much smaller than that of Si-E-CP. The internal diffusion limitation depends on the pores and particle size of the catalyst, and the pore and particle size of Si-CL-CP are $23.5 \mathrm{~nm}$ and $12.8 \mu \mathrm{m}$, which is larger than the $9.1 \mathrm{~nm}$ and $1.4 \mu \mathrm{m}$ of Si-E-CPs. Therefore, since the internal diffusion limit of Si-CL-CPs is relatively smaller than that of $\mathrm{Si}-\mathrm{E}-\mathrm{CPs}$, the formation efficiency of p-NPs is relatively better. Figure $4 \mathrm{c}$ shows the absorption spectra of $\mathrm{p}-\mathrm{NPB}$ as a function of the reaction time with $\mathrm{Si}-\mathrm{CL}-\mathrm{CPs}$. As the reaction time increased, the concentration of formed p-NP increased and was seen at $400 \mathrm{~nm}$. Moreover, the reactant, p-NPB gradually disappeared according to the reaction time. After $25 \mathrm{~min}$, it was completely hydrolyzed, and no absorbance band was observed at $270 \mathrm{~nm}$. Consequently, an isosbestic point was observed at $300 \mathrm{~nm}$. 
(a)

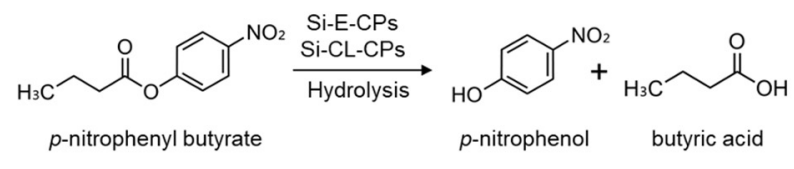

(b)

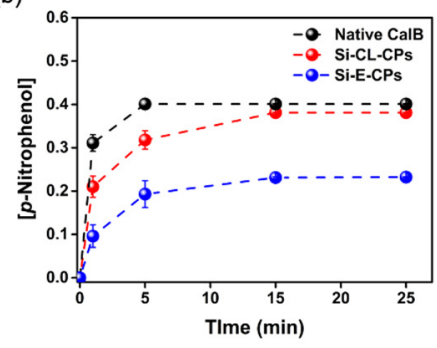

(c)

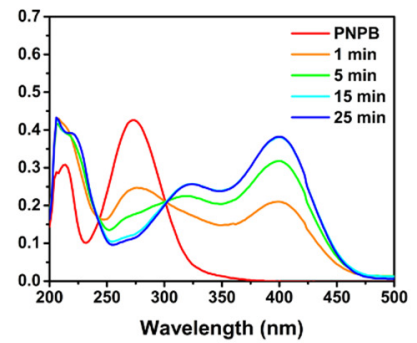

(d)

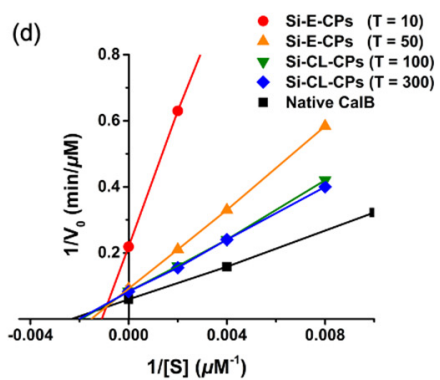

Figure 4. (a) Schemes of enzymatic hydrolysis with Si-CL-CPs against p-NPB to p-NP with native CalB, Si-E-CPs, and Si-CL-CPs (b) absorption spectra of p-NPB as a function of reaction time, and (c) concentration of formed p-NP during the enzymatic hydrolysis with native CalB, Si-E-CPs, and SiCL-CPs, and (d) Lineweaver-Burk plots and Michaelis-Menten parameters of native CalB, Si-E-CPs and Si-CL-CPs as a function of TEOS concentration, respectively.

An isosbestic point is a wavelength at which two chromophores possess the same extinction coefficient. Therefore, this means that two absorbing components, such as $\mathrm{p}$ $\mathrm{NPB}$ and p-NP, are in equilibrium and their relative proportions are controlled by the concentration of another component. At wavelengths before $300 \mathrm{~nm}$, p-NPB, a reactant, was present in the solution, and as the reaction of silica-CalB catalysts proceeded, it means that p-NP was formed at wavelengths after $300 \mathrm{~nm}$. Figure $4 \mathrm{~d}$ shows the enzyme kinetics of the p-NP with native CalB, Si-E-CPs, and Si-CL-CPs from Lineweaver-Burk plots and Michaelis-Menten kinetics. Various enzyme kinetic parameters were calculated from Lineweaver-Burk plots. The Michaelis-Menten constant $\left(\mathrm{K}_{\mathrm{m}}\right)$ shows affinity between enzymes and substrates, and the lower the value, the better the enzyme binds to the substrate [44]. The turnover number $\left(\mathrm{K}_{\mathrm{cat}}\right)$ refers to the number of times each enzyme site converts substrate to product per unit time and the $\mathrm{K}_{\text {cat }} / \mathrm{K}_{\mathrm{m}}$ ratio has been used as a measure of enzyme performance. The enzyme kinetic parameters, such as $\mathrm{K}_{\mathrm{m}}, \mathrm{K}_{\text {cat }}$ and $\mathrm{V}_{\max }$ against native CalB, Si-E-CPs, and Si-CL-CPs are shown in Table 1 . The $\mathrm{K}_{\mathrm{m}}$ value of native CalB was $432.60 \mu \mathrm{M}$, which is lower than the values of Si-E-CPs and SiCL-CPs, and as the concentration of TEOS increased to $10 \mathrm{mM}, 50 \mathrm{mM}, 100.0 \mathrm{mM}$, and $300 \mathrm{mM}$, the $\mathrm{K}_{\mathrm{m}}$ values decreased to $915.32 \mu \mathrm{M}, 588.31 \mu \mathrm{M}, 517.31 \mu \mathrm{M}$, and $497.86 \mu \mathrm{M}$, respectively. However, the $\mathrm{V}_{\text {max }}$ value of native $\mathrm{CalB}$ was $16.86 \mu \mathrm{Mmin}^{-1}$, which decreased to $4.57 \mu \mathrm{Mmin}^{-1}, 9.94 \mu \mathrm{Mmin}^{-1}, 12.02 \mu \mathrm{Mmin}^{-1}$, and $12.06 \mu \mathrm{Mmin}^{-1}$, as the concentration of TEOS increased. The value of $\mathrm{V}_{\max }$ is almost constant at concentrations greater than $100 \mathrm{mM}$. The $\mathrm{K}_{\text {cat }}$ values of native CalB, Si-E-CPs and Si-CL-CPs show a similar tendency to $\mathrm{V}_{\text {max }}$. In Si-E-CPs and Si-CL-CPs, the $\mathrm{K}_{\text {cat }}$ values increased to $5.03 \mathrm{~min}^{-1}, 9.90 \mathrm{~min}^{-1}$, $10.70 \mathrm{~min}^{-1}$, and $10.73 \mathrm{~min}^{-1}$ as the concentration of TEOS increased. Consequently, the catalytic efficiency $\left(\mathrm{K}_{\mathrm{cat}} / \mathrm{K}_{\mathrm{m}}\right)$ shows the order of native CalB $>$ Si-CL-CPs $>$ Si-E-CPs, where the efficiency of Si-E-CPs and Si-CL-CPs is slightly lower than that of native CalB, but it has the advantage of convenient catalytic recovery and shortening time in the reaction process. 
Table 1. Michaelis-Menten parameters of native CalB, Si-E-CPs, and Si-CL-CPs as a function of TEOS concentration for hydrolysis of $\mathrm{p}-\mathrm{NPB}$.

\begin{tabular}{|c|c|c|c|c|c|}
\hline & $\begin{array}{l}\text { [TEOS] } \\
(\mathrm{mM})\end{array}$ & $\begin{array}{c}\mathrm{Km} \\
(\mu \mathrm{M})\end{array}$ & $\begin{array}{c}\mathrm{Vmax} \\
\left(\mu \mathrm{M} \cdots \min ^{-1}\right)\end{array}$ & $\begin{array}{c}\text { Kcat } \\
\left(\min ^{-1}\right)\end{array}$ & $\begin{array}{c}\text { Kcat } / \mathrm{Km} \\
\left(\mathrm{mM}^{-1} \cdots \mathrm{min}^{-1}\right)\end{array}$ \\
\hline Native CalB & 0 & 432.60 & 16.86 & 15.03 & 34.76 \\
\hline \multirow{2}{*}{$\mathrm{Si}-\mathrm{E}-\mathrm{CPS}$} & 10 & 915.32 & 4.57 & 5.03 & 5.50 \\
\hline & 50 & 588.31 & 9.94 & 9.90 & 16.83 \\
\hline \multirow{2}{*}{$\mathrm{Si}-\mathrm{CL}-\mathrm{CPs}$} & 100 & 517.31 & 12.02 & 10.70 & 20.68 \\
\hline & 300 & 497.86 & 12.06 & 10.73 & 21.56 \\
\hline
\end{tabular}

\subsection{Enzymatic Esterification of Benzyl Benzoate with Si-CL-CPS}

The lipase-catalyzed esterification reactions have gained increasing attention in many applications, due to an increased use of organic esters in biotechnology and the chemical industry [45]. For this reason, esterification by lipases has been employed in experiments using either primary or secondary alcohols, or both, free-solvent systems, or organic solvents [46]. However, there are many difficulties in quantitative analysis using UVVis. and HPLC analysis because aliphatic esters obtained from primary or secondary alcohol do not respond to UV-Vis. spectroscopy. Therefore, for the qualitative analysis of aliphatic esters, generally, NMR spectroscopy is used, after separation and purification through column chromatography [47]. To facilitate the quantitative analysis using UV-Vis. spectroscopy of ester compounds, obtained from lipase-catalyzed esterification, lipasecatalyzed esterification was used to synthesize the aromatic ester compounds that are sensitive to UV-Vis. spectroscopy.

Typically, in this work, Si-CL-CPs were demonstrated for the lipase-catalyzed esterification of benzyl benzoate from one or two acyl donors. As shown in Figure 5a, the lipase-catalyzed esterification of benzyl benzoate with Si-CL-CPs is a result of the benzoic acid as an acyl donor and benzoic anhydride as two acyl donors in benzyl alcohol, respectively. Moreover, the yields of benzyl benzoate with Si-CL-CPs are $10 \%$ and $67 \%$, corresponding to the esterification from benzoic acid (one acyl donor) and benzoic anhydride (two acyl donors). This is attributed to benzoic anhydride having two acyl donors (the first acyl donor forms benzyl benzoate and the second acyl donor forms benzoic acid). At this time, the formed benzoic acid may react with residual alcohol and lead to a secondary ester reaction, as shown in Figure $5 b$ [48]. These results indicate that benzoic anhydride is suitable for benzyl benzoate synthesis.

\subsection{Conversion of Benzyl Benzoate from Benzoic Anhydride with Native CalB and Si-CL-CPs}

As described above, in the lipase-catalyzed esterification of benzyl benzoates, benzoic anhydride having two acyl donors was superior to benzoic acid having one acyl donor. Therefore, the conversion efficiency of benzyl benzoate was evaluated using a native CalB enzyme and Si-CL-CPs, as shown in Figure 6a. Figure $6 \mathrm{~b}$ shows the absorption spectra, proton nuclear magnetic resonance $\left({ }^{1} \mathrm{H}-\mathrm{NMR}\right)$ spectra, and thin layer chromatograph (TLC) image of benzoic anhydride and benzyl benzoate, separated by column chromatography, in which benzoic anhydride and benzyl benzoate show the maximum excitation, at $229 \mathrm{~nm}$ and $240 \mathrm{~nm}$, respectively. The ${ }^{1} \mathrm{H}-\mathrm{NMR}$ spectra show chemical shifts of some characteristic peaks of benzoic anhydride and benzyl benzoate, as follows: $8.14-8.20 \mathrm{ppm}(\mathrm{d}, 4 \mathrm{H})$, 7.65-7.71 ppm (t, 2H), and 7.51-7.57 ppm (t, $4 \mathrm{H})$ for benzoic anhydride, and 8.07-8.12 ppm $(\mathrm{d}, 2 \mathrm{H}), 7.54-7.60 \mathrm{ppm}(\mathrm{m}, 1 \mathrm{H}), 7.28-7.49 \mathrm{ppm}(\mathrm{m}, 7 \mathrm{H}), 5.4 \mathrm{ppm}(\mathrm{s}, 2 \mathrm{H})$ for benzyl benzoate, respectively. Moreover, the TLC image shows the perfect separation between benzyl benzoate and benzoic anhydride with the hexane: ethyl acetate (10:1) eluent. Figure $6 c$ shows the change in concentration of benzoic anhydride and benzyl benzoate during the reaction time with native CalB and Si-CL-CPs. The lipase-catalyzed esterification of benzyl benzoates was carried out with a 1:9 molar ratio of benzoic anhydride and benzyl alcohol because an excessive alcohol may lead to secondary esterification with the acid [44-46]. 
During the reaction time for $24 \mathrm{~h}$, the concentration of the benzyl benzoate product through the esterification is gradually increased to $4.51 \mathrm{M}$ and $4.14 \mathrm{M}$, corresponding to native CalB and Si-CL-CPs, respectively. Moreover, the reactant benzoic anhydride decreased to $0.25 \mathrm{M}$ and $0.33 \mathrm{M}$ from $1 \mathrm{M}$, corresponding to native CalB and Si-CL-CPs, respectively. Figure $6 \mathrm{~d}$ shows the conversion efficiency from benzoic anhydride to benzyl benzoate with native CalB and Si-CL-CPs. The conversion efficiency was calculated according to the following equation:

$$
\text { conversion }(\%)=\frac{C_{i}-C_{f}}{C_{i}} \times 100
$$

where $C_{i}$ and $C_{f}$ are the initial and final concentration of reactants (benzoic acid and benzoic anhydride), before and after enzymatic synthesis, respectively. Both native CalB and $\mathrm{Si}$ CL-CPs showed the highest conversion efficiency at $24 \mathrm{~h}$. The conversion efficiency was $75 \%$ and $67 \%$, corresponding to native CalB and Si-CL-CPs, respectively. Although the conversion efficiency of Si-CL-CPs was not much higher than that of native CalB, it has an efficiency of $91 \%$, compared to native CalB, and is expected to be very useful because it has high thermal and $\mathrm{pH}$ stability and excellent reusability.

(a) One acyl donor

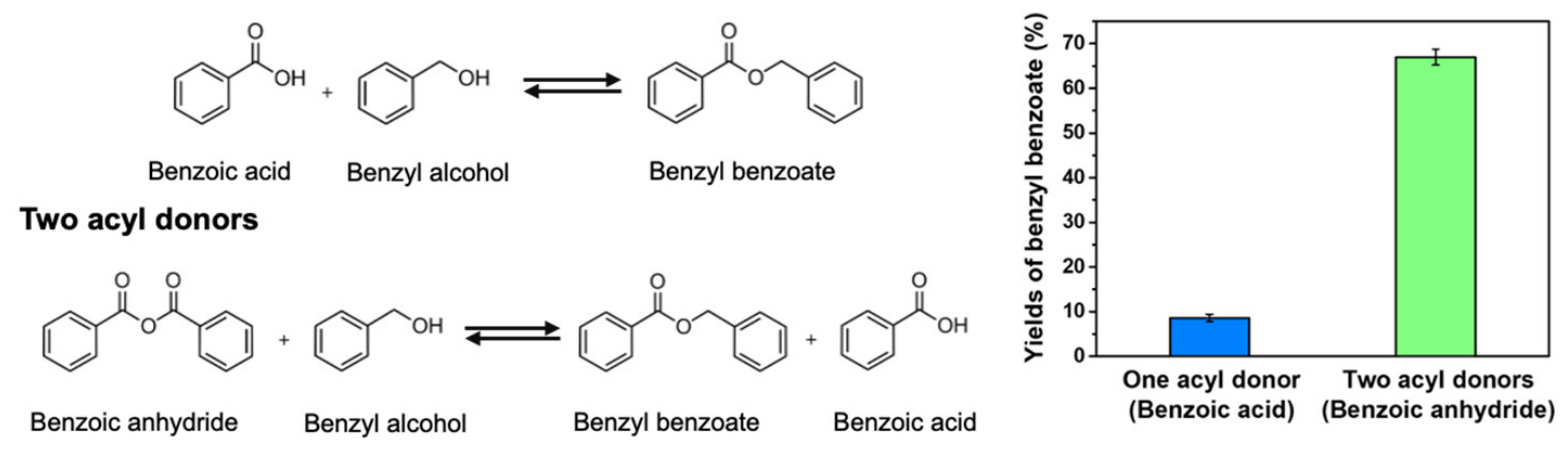

(b)

One acyl donor

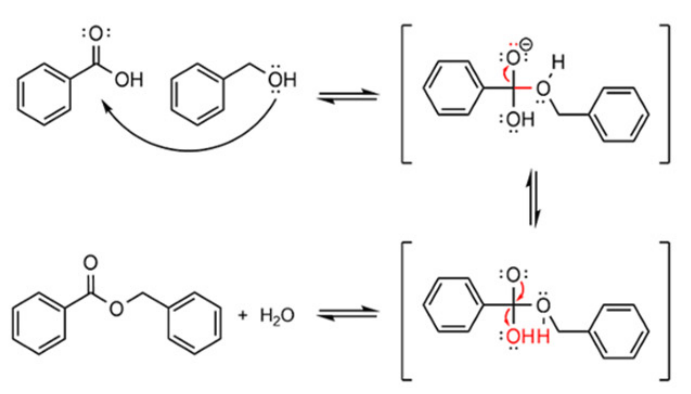<smiles></smiles>

Figure 5. (a) Schemes of enzymatic esterification of benzyl benzoate with the different acyl donors (inserted is the comparison of yields of benzyl benzoate from benzoic anhydride and benzoic acid with Si-CL-CPs), and (b) suggested mechanism. 
(a)

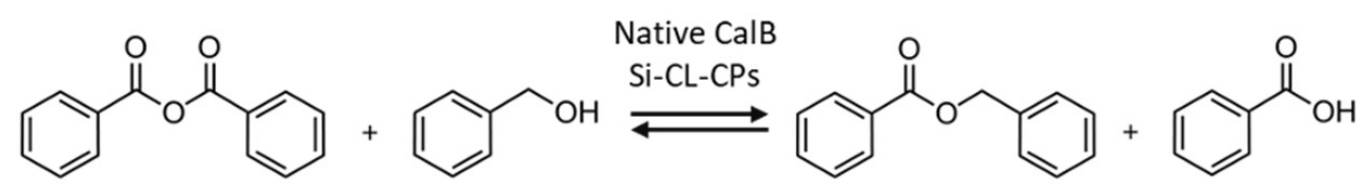

\section{Benzoic anhydride Benzyl alcohol Benzyl benzoate Benzoic acid}

(b)
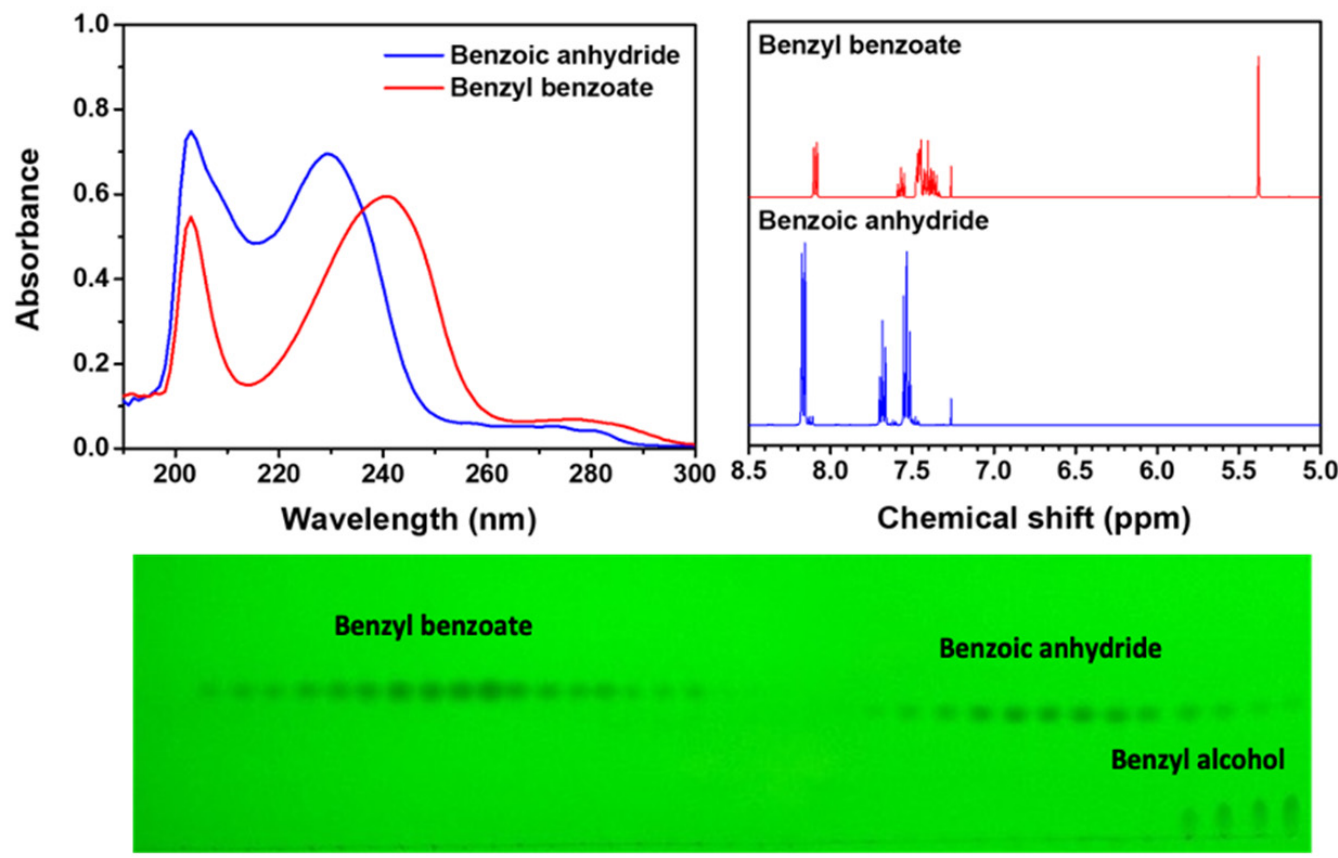

(c)

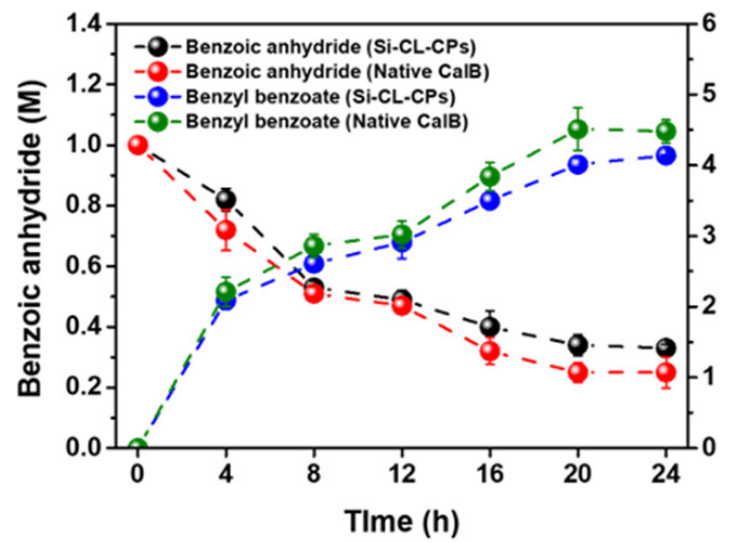

(d)

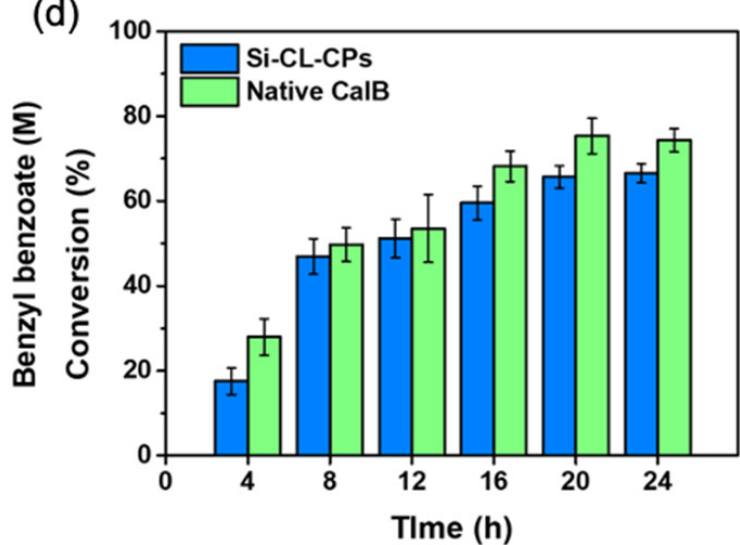

Figure 6. (a) Schemes of enzymatic esterification of benzyl benzoate with benzoic anhydride, (b) comparison of adsorption spectra and 1H-NMR spectra of benzoic anhydride and benzyl benzoate before and after reaction (inserted in the TLC image), (c) correlation of benzoic anhydride and benzyl benzoate concentration changes with native CalB and Si-CL-CPs, and (d) conversion efficiency of benzyl benzoate esterification with native CalB and Si-CL-CPs as a function of reaction.

\section{Materials and Methods}

\subsection{Materials}

Lipase B from Candida antarctica was obtained from Amicogen (33 kDa, Jinju, Korea) and used in encapsulation. Bovine serum albumin (BSA), Coomassie brilliant blue reagent, p-nitrophenyl butyrate ( $\geq 98 \%$, p-NPB), tetraethyl orthosilicate (99\%, TEOS), benzoic anhydride, benzoic acid, benzyl alcohol, trizma base, phosphate buffer saline (PBS) and sodium citrate were purchased from Sigma-Aldrich (Seoul, Korea). Hexane, ethyl acetate and 
hydrochloric acid were provided by Daejung (Seoul, Korea) and other chemicals were of analytical grade.

\subsection{Preparation of Si-E-CPs and Si-CL-CPs}

Si-E-CPs and Si-CL-CPs were prepared according to the sol-gel method [49-51]. Various concentrations (range, 11.5-307.2 mM) of TEOS and $1 \mathrm{~mL}$ of $0.1 \mathrm{M} \mathrm{HCl}$ were added in $10 \mathrm{~mL}$ of deionized water. To make a homogeneous solution, the mixed solution was vigorously agitated for $10 \mathrm{~min}$ at room temperature. Subsequently, $1.4 \mathrm{~g}$ of CalB lipase was suspended in $50 \mathrm{~mL}$ of phosphate buffer (PBS, $10 \mathrm{mM}, \mathrm{pH}$ 7.2). The lipase solution was added into the silica precursor solution. The mixture was intensively agitated for $15 \mathrm{~min}$ (gelation occurred after a few seconds) and continuously stirred for $8 \mathrm{~h}$ at $400 \mathrm{rpm}$. The obtained gel was freeze-dried for a day.

\subsection{Determination of CalB Enzyme Amounts in Si-E-CPs and Si-CL-CPs}

The amount of entrapped CalB enzyme was determined by the Bradford method using Coomassie brilliant blue reagent $[52,53]$. The CalB enzyme content was estimated comparing the concentration differences between the originally added enzyme solution and the washing solution. Bovine serum albumin (BSA) was used as a standard. The absorbance was measured at $595 \mathrm{~nm}$ by UV-Vis. spectrophotometry.

\subsection{Thermal Stability and $p H$ Activity of Native CalB, Si-E-CPs, and Si-CL-CPS}

The thermal stability and the $\mathrm{pH}$ activity of native $\mathrm{CalB}, \mathrm{Si}-\mathrm{E}-\mathrm{CPs}$, and $\mathrm{Si}-\mathrm{CL}-\mathrm{CPs}$ were determined by the catalytic activity using $\mathrm{p}-\mathrm{NPB}$ under various temperature $\left(25-65^{\circ} \mathrm{C}\right)$ and $\mathrm{pH}(0.1 \mathrm{M}$ sodium citrate for $\mathrm{pH} 5-6,0.1 \mathrm{M}$ tris- $\mathrm{HCl}$ for $\mathrm{pH} 7-9)$ conditions. Each mixture was incubated for $20 \mathrm{~min}$ and centrifuged at 15,000 rpm for $1 \mathrm{~min}$. Catalytic activities were calculated at optimum temperature and $\mathrm{pH}$ conditions.

\subsection{Reusability of Si-E-CPs and Si-CL-CPs}

Reusability of Si-E-CPs and Si-CL-CPs was evaluated in repeated cycles with pnitrophenyl butyrate (p-NPB). The Si-E-CPs and Si-CL-CPs were recovered from the reaction medium by centrifugation at 15,000 rpm for $1 \mathrm{~min}$ and washed with tris- $\mathrm{HCl}$ buffer $(0.1 \mathrm{M}, \mathrm{pH} 7.2)$ to remove any residual substrate. The process was repeated for up to seven cycles to examine the reusability of the catalysts.

\subsection{Enzymatic Hydrolysis for p-Nitrophenyl Butyrate}

Enzymatic hydrolysis was achieved against p-nitrophenyl butyrate (p-NPB) with native CalB, Si-E-CPs, and Si-CL-CPs, respectively. The stock solution of p-NPB $(0.1 \mathrm{M})$ was prepared and diluted in different concentrations $(0.125-0.5 \mathrm{mM})$ with tris- $\mathrm{HCl}$ buffer $(0.1 \mathrm{M}$, pH 7.2). Next, $1.3 \mu \mathrm{L}$ of native CalB $(28.3 \mathrm{mg} / \mathrm{mL})$ and $0.1 \mathrm{mg}$ of Si-E-CPs, and Si-CL-CPs were added in $1 \mathrm{~mL}$ of substrate solution and incubated for $5 \mathrm{~min}$ at R.T. The mixture was centrifuged at 15,000 rpm for $1 \mathrm{~min}$. The absorbance of the product, p-nitrophenol (p-NP), was measured at $400 \mathrm{~nm}$ by UV-Vis. The catalytic parameters such as Michaelis-Menten constant $\left(\mathrm{K}_{\mathrm{m}}\right)$, maximum reaction velocity $\left(\mathrm{V}_{\max }\right)$ and turnover value $\left(\mathrm{K}_{\mathrm{cat}}\right)$ were calculated for native CalB, Si-E-CPs, and Si-CL-CPs, respectively.

\subsection{Enzymatic Synthesis for Benzyl Benzoate with Native CalB and Si-CL-CPs}

Benzoic acid and benzyl alcohol were mixed in 1:9 molar ratio for enzymatic esterification. Next, $0.5 \mathrm{~g}$ of Si-CL-CPs and $0.185 \mathrm{~g}$ of native CalB were added to the mixture and incubated on a rotary shaker at $50{ }^{\circ} \mathrm{C}$ for $4,8,12,16,20$, and $24 \mathrm{~h}$, respectively. After the reaction was completed, the supernatant of benzoic acid was separated by centrifugation at $4000 \mathrm{rpm}$ for $20 \mathrm{~min}$. For the enzymatic acylation, benzoic anhydride and benzyl alcohol were mixed in a 1:9 molar ratio. The experiment was carried out in duplicate. The extracted supernatants were separated by column chromatography, and the solvent was evaporated using a rotary evaporator after thin layer chromatography (TLC) analysis. The formation 
of benzyl benzoate was confirmed by measuring the absorbance at $229 \mathrm{~nm}$ using a UV-Vis. spectrophotometer.

\subsection{Instrumental Analysis}

The morphological details of Si-E-CPs and Si-CL-CPs as a function of TEOS concentration were investigated by field emission scanning electronic microscopy (FE-SEM) using a Mira-3 instrument (Tescan, Brno, Czech Republic) with $2 \mathrm{kV}$ accelerating voltage. To evaluate the amount of encapsulated CalB enzyme in Si-E-CPs and Si-CL-CPs, a thermogravimetric analysis (TGA) was performed from room temperature to $700{ }^{\circ} \mathrm{C}$ at a

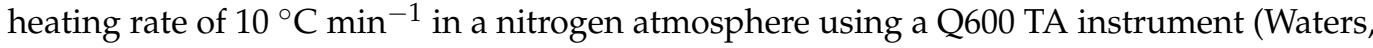
New Castle, DE, USA). Fourier transform infrared (FT-IR) spectroscopy and dynamic light scattering (DLS) were carried out for identification and characterization of Si-E-CPs and Si-CL-CPs. FT-IR spectra were measured with a $\mathrm{KBr}$ compressed pellet in wavelength range of 450-4000 $\mathrm{cm}^{-1}$ using an SDT Q600 Frontier (Perkin Elmer, Houston, TX, USA). Particle sizes of Si-E-CPs, and Si-CL-CPs were evaluated using a ZEN 3600 (Malvern, UK). UV-Vis. spectra were measured by Mega 900 (SCINCO, Seoul, Korea) in a range of 190-500 nm. ${ }^{1} \mathrm{H}-\mathrm{NMR}$ spectra were measured on a Bruker Advance III 400 spectrometer $(400 \mathrm{MHz})$ (Seoul, Korea) using $\mathrm{CDCl}_{3}$ solutions and TMS as an internal standard. Chemical shifts are reported in parts per million ( $\mathrm{ppm}, \mathrm{d}$ ) relative to the internal tetramethylsilane standard (TMS, $d$ 0.00). The peak patterns are indicated (s, singlet; $d$, doublet; $t$, triplet; $\mathrm{m}$, multiplet). Column chromatography was generally performed on silica gel (pore size $60 \AA, 32-63 \mathrm{~nm}$ particle size) and reactions were monitored by a thin-layer chromatography (TLC) analysis performed with Merck Kieselgel 60 F254 plates and visualized using UV light at $240 \mathrm{~nm}$.

\section{Conclusions}

Si-E-CPs and Si-CL-CPs were prepared as a function of TEOS concentration, in the ranges of 10 to $50 \mathrm{mM}$ and 100 to $300 \mathrm{mM}$, respectively. The prepared Si-E-CPs and Si-CLCPs had different particle sizes and morphology, depending on the TEOS concentration, such as uniformed spheres and irregular aggregates. These materials demonstrated thermal and $\mathrm{pH}$ stability under various temperature and $\mathrm{pH}$ conditions. Reusability was also demonstrated, compared with the native CalB enzyme. With these materials, enzymatic hydrolysis against the p-NPB and enzymatic esterification of benzyl benzoate with one acyl donor in benzoic acid and two acyl donors in benzoic anhydride was demonstrated. The esterification efficiency of Si-CL-CPs was higher in benzoic anhydride than in benzoic acid. Furthermore, the conversion efficiency to benzyl benzoate, corresponding to native CalB and Si-CL-CPs, was $75 \%$ and $67 \%$, respectively. Although the conversion efficiency of Si-CL-CPs was not much higher than that of native CalB, it has an efficiency of $91 \%$ compared to native $\mathrm{CalB}$, and is expected to be very useful because it has high thermal and pH stability and excellent reusability.

Author Contributions: Conceptualization, J.-H.C.; methodology, J.-H.C.; data curation, M.S.; writing-original draft preparation, M.S.; writing—review and editing, J.-H.C.; supervision, J.-H.C.; project administration, J.-H.C.; funding acquisition, J.-H.C. All authors have read and agreed to the published version of the manuscript.

Funding: This work was carried out with the support of "Cooperative Research Program for Agriculture Science and Technology Development (Project No. PJ01493802)" Rural Development Administration, Republic of Korea.

Institutional Review Board Statement: Not applicable.

Informed Consent Statement: Not applicable.

Conflicts of Interest: The authors declare no conflict of interest. 


\section{References}

1. Wang, Y.; Caruso, F. Enzyme encapsulation in nanoporous silica spheres. Chem. Comm. 2004, 13, 1528-1529. [CrossRef] [PubMed]

2. Soldatkin, O.; Kucherenko, I.; Pyeshkova, V.; Kukla, A.; Jaffrezic-Renault, N.; El'Skaya, A.; Dzyadevych, S.; Soldatkin, A. Novel conductometric biosensor based on three-enzyme system for selective determination of heavy metal ions. Bioelectrochemistry 2012, 83, 25-30. [CrossRef] [PubMed]

3. Gomes-Ruffi, C.R.; da Cunha, R.H.; Almeida, E.L.; Chang, Y.K.; Steel, C.J. Effect of the emulsifier sodium stearoyl lactylate and of the enzyme maltogenic amylase on the quality of pan bread during storage. LWT 2012, 49, 96-101. [CrossRef]

4. Schoemaker, H.E.; Mink, D.; Wubbolts, M.G. Dispelling the myths-Biocatalysis in industrial synthesis. Science 2003, 299, 1694-1697. [CrossRef] [PubMed]

5. Shaw, N.M.; Robins, K.T.; Kiener, A. Lonza: 20 years of biotransformations. Adv. Synth. Catal. 2003, 345, 425-435. [CrossRef]

6. Sheldon, R.A. Enzyme immobilization: The quest for optimum performance. Adv. Synth. Catal. 2007, 349, 1289-1307. [CrossRef]

7. Sheldon, R.A.; van Rantwijk, F. Biocatalysis for sustainable organic synthesis. Aust. J. Chem. 2004, 57, 281-289. [CrossRef]

8. Homaei, A.A.; Sariri, R.; Vianello, F.; Stevanato, R. Enzyme immobilization: An update. J. Chem. Biol. 2013, 6, 185-205. [CrossRef]

9. Romero, M.; Calvo, L.; Alba, C.; Daneshfar, A.; Ghaziaskar, H. Enzymatic synthesis of isoamyl acetate with immobilized Candida antarctica lipase in n-hexane. Enzyme Microb. Technol. 2005, 37, 42-48. [CrossRef]

10. Stergiou, P.-Y.; Foukis, A.; Filippou, M.; Koukouritaki, M.; Parapouli, M.; Theodorou, L.G.; Hatziloukas, E.; Afendra, A.; Pandey, A.; Papamichael, E.M. Advances in lipase-catalyzed esterification reactions. Biotechnol. Adv. 2013, 31, 1846-1859. [CrossRef]

11. Stauch, B.; Fisher, S.J.; Cianci, M. Open and closed states of Candida antarctica lipase B: Protonation and the mechanism of interfacial activation1. J. Lipid Res. 2015, 56, 2348-2358. [CrossRef] [PubMed]

12. Anderson, E.M.; Larsson, K.M.; Kirk, O. One biocatalyst-Many applications: The use of Candida antarctica B-lipase in organic synthesis. Biocatal. Biotransform. 1998, 16, 181-204. [CrossRef]

13. Rotticci, D.; Rotticci-Mulder, J.C.; Denman, S.; Norin, T.; Hult, K. Improved enantioselectivity of a lipase by rational protein engineering. ChemBioChem 2001, 2, 766-770. [CrossRef]

14. Idris, A.; Bukhari, A. Immobilized Candida antarctica lipase B: Hydration, stripping off and application in ring opening polyester synthesis. Biotechnol. Adv. 2012, 30, 550-563. [CrossRef] [PubMed]

15. Martinelle, M.; Holmquist, M.; Hult, K. On the interfacial activation of Candida antarctica lipase A and B as compared with Humicola lanuginosa lipase. Biochim. Biophys. Acta (BBA)-Lipids Lipid Metabol. 1995, 1258, 272-276. [CrossRef]

16. Kundys, A.; Białecka-Florjańczyk, E.; Fabiszewska, A.; Małajowicz, J. Candida antarctica lipase B as catalyst for cyclic esters synthesis, their polymerization and degradation of aliphatic polyesters. J. Polym. Environ. 2018, 26, 396-407. [CrossRef]

17. Weiser, D.; Boros, Z.; Hornyánszky, G.; Tóth, A.; Poppe, L. Disubstituted dialkoxysilane precursors in binary and ternary sol-gel systems for lipase immobilization. Process Biochem. 2012, 47, 428-434. [CrossRef]

18. Datta, S.; Christena, L.R.; Rajaram, Y.R.S. Enzyme immobilization: An overview on techniques and support materials. 3 Biotech 2013, 3, 1-9. [CrossRef]

19. Murty, V.R.; Bhat, J.; Muniswaran, P. Hydrolysis of oils by using immobilized lipase enzyme: A review. Biotechnol. Bioprocess Eng. 2002, 7, 57-66. [CrossRef]

20. Krajewska, B. Application of chitin-and chitosan-based materials for enzyme immobilizations: A review. Enzym. Microb. Technol. 2004, 35, 126-139. [CrossRef]

21. Iyer, P.V.; Ananthanarayan, L. Enzyme stability and stabilization-Aqueous and non-aqueous environment. Process Biochem. 2008, 43, 1019-1032. [CrossRef]

22. Mateo, C.; Palomo, J.M.; Fernandez-Lorente, G.; Guisan, J.M.; Fernandez-Lafuente, R. Improvement of enzyme activity, stability and selectivity via immobilization techniques. Enzym. Microb. Technol. 2007, 40, 1451-1463. [CrossRef]

23. Avnir, D.; Coradin, T.; Lev, O.; Livage, J. Recent bio-applications of sol-gel materials. J. Mater. Chem. 2006, 16, 1013-1030. [CrossRef]

24. Malcata, F.X.; Hill, C.G., Jr.; Amundson, C.H. Use of a lipase immobilized in a membrane reactor to hydrolyze the glycerides of butteroil. Biotechno. Bioeng. 1991, 38, 853-868. [CrossRef] [PubMed]

25. Sheldon, R. Cross-linked enzyme aggregates $\left(\right.$ CLEA $^{\circledR}$ s): Stable and recyclable biocatalysts. Biochem. Soc. Trans. 2007, 35, 1583-1587. [CrossRef]

26. Cao, L.; van Langen, L.; Sheldon, R.A. Immobilised enzymes: Carrier-bound or carrier-free? Curr. Opin. Biotechnol. 2003, 14, 387-394. [CrossRef]

27. Uyanik, A.; Sen, N.; Yilmaz, M. Improvement of catalytic activity of lipase from Candida rugosa via sol-gel encapsulation in the presence of calix (aza) crown. Bioresour. Technol. 2011, 102, 4313-4318. [CrossRef]

28. Yang, G.; Wu, J.; Xu, G.; Yang, L. Improvement of catalytic properties of lipase from Arthrobacter sp. by encapsulation in hydrophobic sol-gel materials. Bioresour. Technol. 2009, 100, 4311-4316. [CrossRef]

29. Mohamed, M.G.; Kuo, S.W. Functional polyimide/polyhedral oligomeric silsesquioxane nanocomposites. Polymers 2019, 11, 26. [CrossRef] [PubMed]

30. Mohamed, M.G.; Kuo, S.W. Functional silica and carbon nanocomposites based on polybenzooxazines. Macromol. Chem. Phys. 2019, 220, 1800306. [CrossRef] 
31. Cui, J.; Jia, S.; Liang, L.; Zhao, Y.; Feng, Y. Mesoporous CLEAs-silica composite microparticles with high activity and enhanced stability. Sci. Rep. 2015, 5, 14203. [CrossRef] [PubMed]

32. Luckarift, H.R.; Spain, J.C.; Naik, R.R.; Stone, M.O. Enzyme immobilization in a biomimetic silica support. Nat. Biotechnol. 2004, 22, 211-213. [CrossRef] [PubMed]

33. Pierre, A. The sol-gel encapsulation of enzymes. Biocatal. Biotransform. 2004, 22, 145-170. [CrossRef]

34. Soares, C.M.; dos Santos, O.A.; Olivo, J.E.; de Castro, H.F.; de Moraes, F.F.; Zanin, G.M. Influence of the alkyl-substituted silane precursor on sol-gel encapsulated lipase activity. J. Mol. Catal. B Enzym. 2004, 29, 69-79. [CrossRef]

35. Garcia-Galan, C.; Berenguer-Murcia, Á.; Fernandez-Lafuente, R.; Rodrigues, R.C. Potential of different enzyme immobilization strategies to improve enzyme performance. Adv. Synth. Catal. 2011, 353, 2885-2904. [CrossRef]

36. Babich, L. Enzymatic Cascade Reactions Involving Phosphorylated Intermediates: Immobilization and Process Optimization. Ph.D. Thesis, Universiteit van Amsterdam, Amsterdam, The Netherlands, 2013.

37. Cao, L.; van Rantwijk, F.; Sheldon, R.A. Cross-linked enzyme aggregates: A simple and effective method for the immobilization of penicillin acylase. Org. Lett. 2000, 2, 1361-1364. [CrossRef]

38. Sheldon, R.A. Cross-linked enzyme aggregates as industrial biocatalysts. Org. Proc. Res. Develop. 2011, 15, 213-223. [CrossRef]

39. Jegan Roy, J.; Emilia Abraham, T. Strategies in making cross-linked enzyme crystals. Chem. Rev. 2004, 104, 3705-3722. [CrossRef]

40. Ibrahim, I.A.; Zikry, A.; Sharaf, M.A. Preparation of spherical silica nanoparticles: Stober silica. J. Am. Sci. 2010, 6, 985-989.

41. Lindberg, R.; Sjöblom, J.; Sundholm, G. Preparation of silica particles utilizing the sol-gel and the emulsion-gel processes. Colloids Surf. A Physicochem. Eng. Asp. 1995, 99, 79-88. [CrossRef]

42. Lindberg, R.; Pettersen, B.; Sjo, J.; Friberg, S.E. Multivariate analysis of the size dependence of monodisperse silica particles prepared according to the sol-gel technique. Colloids Surf. A Physicochem. Eng. Asp. 1997, 123, 549-560. [CrossRef]

43. Nguyen, D.T.; Smit, M.; Dunn, B.; Zink, J.I. Stabilization of creatine kinase encapsulated in silicate sol-gel materials and unusual temperature effects on its activity. Chem. Mater. 2002, 14, 4300-4306. [CrossRef]

44. Duman, Y.A.; Tekin, N. Kinetic and thermodynamic properties of purified alkaline protease from Bacillus pumilus Y7 and non-covalent immobilization to poly (vinylimidazole)/clay hydrogel. Eng. Life Sci. 2020, 20, 36-49. [CrossRef]

45. Torres, S.; Castro, G.R. Non-aqueous biocatalysis in homogeneous solvent systems. Food Technol. Biotechnol. $2004,42,271-277$.

46. Gandhi, N.N.; Patil, N.S.; Sawant, S.B.; Joshi, J.B.; Wangikar, P.P.; Mukesh, D. Lipase-catalyzed esterification. Catal. Rev. 2000, 42, 439-480. [CrossRef]

47. Politzer, I.; Griffin, G.; Dowty, B.; Laseter, J. Enhancement of ultraviolet detectability of fatty acids for purposes of liquid chromatographic-mass spectrometric analyses. Anal. Lett. 1973, 6, 539-546. [CrossRef]

48. de Meneses, A.C.; Balen, M.; de Andrade Jasper, E.; Korte, I.; de Araújo, P.H.H.; Sayer, C.; de Oliveira, D. Enzymatic synthesis of benzyl benzoate using different acyl donors: Comparison of solvent-free reaction techniques. Process Biochem. 2020, 92, 261-268. [CrossRef]

49. Reetz, M.T. Entrapment of biocatalysts in hydrophobic sol-gel materials for use in organic chemistry. Adv. Mater. 1997, 9, 943-954. [CrossRef]

50. Chen, Q.; Kenausis, G.L.; Heller, A. Stability of oxidases immobilized in silica gels. J. Am. Chem. Soc. 1998, $120,4582-4585$. [CrossRef]

51. Obert, R.; Dave, B.C. Enzymatic conversion of carbon dioxide to methanol: Enhanced methanol production in silica sol-gel matrices. J. Am. Chem. Soc 1999, 121, 12192-12193. [CrossRef]

52. Zor, T.; Selinger, Z. Linearization of the Bradford protein assay increases its sensitivity: Theoretical and experimental studies. Anal. Biochem. 1996, 236, 302-308. [CrossRef] [PubMed]

53. Ernst, O.; Zor, T. Linearization of the Bradford protein assay. J. Vis. Exp. 2010, 38, e1918. [CrossRef] [PubMed] 